\title{
GAMBARAN BRAND IDENTIFICATION DAN BRAND LOVES PADA PENGGUNA FORUM JUAL BELI KASKUS DI KOTA BANDUNG
}

\author{
Fajar Gumelar Maulana ${ }^{1}$ \\ Universitas Pendidikan Indonesia \\ gumelarajay@gmail.com \\ Lili Adi Wibowo ${ }^{1}$ \\ Universitas Pendidikan Indonesia \\ Liliadiwibowo@upi.edu \\ Bambang Widjajanta ${ }^{1}$ \\ Universitas Pendidikan Indonesia \\ bambangwidjajanta@upi.edu
}

\begin{abstract}
ABSTRAK
Tujuan - Untuk mengetahui gambaran tingkat brand identification dan brand loves pada pengguna forum jual beli kaskus di Kota Bandung.

Desain/metodologi/pendekatan - Desain penelitian ini adalah cross sectional method. Penelitian ini menggunakan pendekatan deskriptif dengan metode explanatory survei. Sebanyak 107 responden dipilih dengan menggunakan non-probability sampling. Sebuah kuesioner digunakan sebagai instrumen penelitian untuk mengumpulkan data dari responden. Teknik analisis yang digunakan adalah teknik deskriptif dengan menggunakan distribusi frekuensi.

Temuan - Hasil penelitian menunjukkan bahwa gambaran brand identification berada pada kategori cukup baik dan gambaran brand loves berada pada kategori sedang.

Orisinalitas/nilai - Perbedaan dalam penelitian ini terletak pada objek penelitian, waktu penelitian, alat ukur, literatur yang digunakan, teori yang digunakan dan hasil penelitian
\end{abstract}

Kata Kunci: Brand identification, Brand Loves, Kaskus

Tipe Artike:1 Studi Kasus

\begin{abstract}
Purpose - To find out the description of the level of brand identification and brand loves in kaskus buyerseller forum user Bandung City.

Design/methodology/approach - The design of this study is cross sectional method. This research uses descriptive approach with explanatory survey method. A total of 107 respondents were selected using probability sampling. A questionnaire was used as a research instrument to collect data from respondents. The analysis technique used is descriptive technique by using frequency distribution.

Findings - The result showed that brand identification is in good enough category, while brand loves is in medium category.

Originality / value - The differences in this study located on an object research, time research, a measuring instrument, literature that used, the theory that is used and the results of the study
\end{abstract}

Keywords: Brand identification, Brand loves, Kaskus

Article Type: Research Paper

\section{PENDAHULUAN}

Brand dapat dikatakan sebagai pembangun profil penting perusahaan dan menjadi aset penting bagi perusahaan (Baena, 2016). Membangun konsep brand loves pada perusahaam bertujuan untuk mengukur perasaan cinta konsumen terhadap brand yang diyakininya tersebut (Sæther;, 2014). Perasaan cinta memiliki identitas inti tetapi juga harus mencakup aspek identitas yang memberikan daya dan kekuatan (Cortsen \& Cortsen, 2013). Menumbuhkan brand loves menjadi perhatian 
utama pada perusahaan-perusahaan yang pada umumnya sekarang banyak di gemari masyarakat. (Abosag, Roper, \& Hind, 2012).

$$
\text { Brand loves pertama kali }
$$

dikonseptualisasikan oleh Shimp dan Madden (1988). Konsistensi penting pada brand loves juga mengingat perasaan pribadi dan pengalaman dari konsumen dikenakan naluri perubahan diri menentukan kearah positif atau negatif (Norris, Wann, \& Zapalac, 2015). Perubahan ini disebabkan oleh tindakan pribadi dari pecinta merek. Kepribadian inilah yang menjadi hubungan antara konsumen dan brand loves (Williams, Pedersen, \& Walsh, 2012).

Konsep baru brand loves muncul di bidang perilaku konsumen. Kesempatan konsumen menyukai brand, maka volume penjualan dari brand akan meningkat, sebagai brand loves akan berubah menjadi loyalitas (Albert, Management, \& Merunka, 2013). Brand loves ini juga sangat dibutuhkan oleh sikap konsumen terhadap kepuasan yang terjadi. kebutuhan brand loves harus dikonseptualisasikan dari bawah ke atas, dibangun di atas pemahaman yang mendalam tentang bagaimana konsumen mengalaminya, dan kemudian harus memberikan koneksi yang baik dengan dibuat untuk literatur cinta interpersonal sehingga konsumen dapat merasakannya (Batra, Ahuvia, Bagozzi, \& Love, 2012).

Penelitian tentang brand love telah menjadi trend dalam kajian beberapa peneliti terutama dalam perusahaan startup forum jual beli khususnya pada online (Popp, Germelmann, \& Jung, 2016). Transaksi online ini pada tahun akhir 2016 sekitar 36,8\% atau sekitar 46,1 juta. Forum jual beli yang banyak didukung oleh penggemarnya dalam artian member ini juga banyak diteliti yang pada akhirnya timbul brand loves yang khususnya menggemari komunitas tersebut. Kajian yang lebih mutakhir juga menunjukkan bahwa konsumen dapat mengalami perasaan cinta untuk merek tertentu merujuk pada karya manifestasi, studi kecintaan merek cenderung berfokus pada konseptualisasinya dan pengukuran, tetapi bahkan sebagai kecintaan merek yang muncul sebagai hubungan konsumen dengan merek yang penting, sedikit tentang apa yang menghasilkan hubungan cinta (Albert, 2013). Fakta bahwa pasar jual beli itu sendiri sudah banyak digemari masyarakat, berarti bahwa brand yang kuat dan relevan bisa berpotensi meningkatkan nilai komersial dari forum jual beli dan membuat lingkaran berbudi luhur yang mengarah ke peningkatan pendapatan (Abosag et al., 2012). Para peneliti sekarang telah memberikan bukti bahwa brand love terutama pada forum jual beli online yang dirasakan, meningkatkan kehidupan sosial seseorang dan mencerminkan batin berhubungan positif.

Forum jual beli online yang menjadi viral di Indonesia, tetapi banyak juga kegagalan yang dirasakan oleh perusahaan startup terutama pada forum jual beli. Meningkatnya persaingan yang tinggi sangatlah sulit untuk perusahaan beradaptasi pada pasar yang sudah ada. Munculnya berbagai layanan dan akses yang mudah dapat membuat perusahaan lainnya menjadi terancam mengalami kegagalan. (Albert, 2013).

Top 6 Traffic Rank Website Startup Ecommerce menunjukan beberapa perusahaan startup e-commerce yang berhasil mendapatkan keunggulan untuk bersaing. Posisi pertama berhasil ditempati oleh perusahaan Tokopedia dengan perolehan global rank yaitu 55, hal ini menunjukan bahwa perusahaan dapat bersaing dan unggul dibandingkan perusahaan yang lainnya dapat dilihat melalui Tabel 1 berikut.

Tabel 1 Top 6 Traffic Rank Website Startup ecommerce

\begin{tabular}{lcc}
\hline $\begin{array}{c}\text { Perusahaan } \\
\text { Startup }\end{array}$ & $\begin{array}{c}\text { Regional } \\
\text { Rank }\end{array}$ & $\begin{array}{c}\text { Global } \\
\text { Rank }\end{array}$ \\
\hline Tokopedia & 1 & 55 \\
Lazada & 2 & 63 \\
Bukalapak & 3 & 69 \\
Blibli & 4 & 103 \\
Traveloka & 5 & 154 \\
Elevania & 6 & 168 \\
\hline
\end{tabular}

Sumber: startuprangking.com diakses 15 Maret 2017

Data mengenai perusahaan startup jual beli online Indonesia akan ditunjukkan melalui Tabel 2. Informasi ini menunjukan keadaan perusahaan forum jual beli. Posisi country rank menunjukkan bahwa forum jual beli Kaskus lebih unggul dibandingkan dengan forum jual beli online lainnya. Perolehan tertinggi dalam forum jual beli berhasil diraih pada posisi ke 12, hal tersebut diasumsikan bahwa konsumen memiliki tingkat cinta yang lebih tinggi terhadap brand Kaskus.

Tabel 2 Perusahaan dan Forum Jual Beli di Indonesia

\begin{tabular}{ccc}
\hline Perusahaan & $\begin{array}{c}\text { Country } \\
\text { Rank }\end{array}$ & $\begin{array}{c}\text { Global } \\
\text { Rank }\end{array}$ \\
\hline FORUM JUAL BELI & 12 & 317 \\
KASKUS & & \\
OLX & 41 & 1.296 \\
Blanja.com & 126 & 7.669 \\
Shopee.co.id & 134 & 7.742 \\
\hline
\end{tabular}

Sumber : alexa.com, diakses tanggal 15 Maret 2017

Forum jual beli Kaskus merupakan salah satu perusahan startup yang merupakan anak dari kaskus.co.id yang sedang berkembang di Indonesia dimana lebih dari 5.000 orang dan ada 5 negara yang sudah sudah mengikutinya 
dibandingkan dengan perusahaan yang menjadi forum jual beli di Indonesia. Posisi pada perusahaan-perusahaan startup di Indonesia memiliki nilai startup rank score (SR score) yang pentingnya perusahaan dihitung berdasarkan rank. Gambar 1 posisi Kaskus dalam waktu satu minggu dibulan Maret mengalami kondisi yang sangat datar tidak ada kenaikan dan menurun.

Gambar 1 Posisi Kaskus Pada Perusahaan Jual Beli di Indonesia

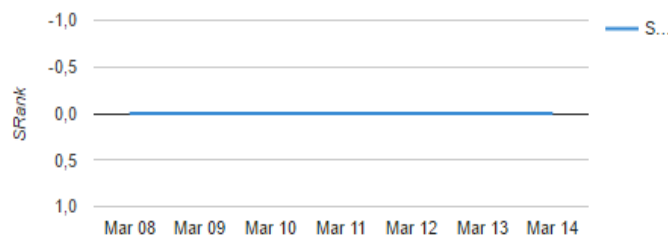

Sumber : startupranking.com, diakses 14 Maret 2017

Perusahaan startup perlu membangun brand loves agar semakin kuat posisinya dalam benak konsumen (Kingdom, Sallam, Arabia, Wahid, \& Network, 2015). Kaskus selama beberapa tahun terakhir, selalu mengalami penurunan dalam hal penempatan posisi di benak konsumen. Tabel 3 tentang posisi Kaskus Tahun 2012 sampai 2016, 2012 persentase dari kaskus naik samapi ke tahun 2013, dan setelah itu kaskus mengalami penurunan, hal tersebut menunjukkan bahwa kecintaan konsumen terhadap brand kaskus mengalami penurunan.

Tabel 3 Posisi Kaskus Di Top Brand Jual Beli

\begin{tabular}{ccc}
\hline TAHUN & POSISI & PERSENTASE \\
\hline 2012 & 2 & $15,6 \%$ \\
2013 & 2 & $18,4 \%$ \\
2014 & 3 & $4,5 \%$ \\
2015 & 4 & $0,9 \%$ \\
2016 & 5 & $0,8 \%$ \\
\hline
\end{tabular}

Sumber : topbrand-awards.com, diakses tanggal 20 Maret 2017

Dampak masalah dari adanya brand loves untuk konsumen, masalah yang timbul ini menjadi hal positif dan negatif dalam peranannya. Brand loves akan menciptakan loyalitas pelanggan sehingga jika perusahan tidak bisa memenuhi hal tersebut maka perusahaan tidak akan mendapatkan loyalitas dari pelanggannya dan tidak seutuhnya merasakan kedekatan (Rageh, 2012). Brand love yang dipengaruhi oleh tingkat kepuasaan konsumen yang tinggi terkait dengan perilaku konsumen, akan sangat mempengaruhi tingginya loyalitas merek terlebih untuk terlibat dalam melakukan positive word of mouth ke berbagai pihak. Positive word of mouth digunakan sebagai sarana komunikasi (Evans \& Smith, 2004).
Pendekatan atau teori yang diapakai dalam brand loves ini yaitu teori consumer brand relationship oleh Susan Fournier tahun 2012, yang mengemukakan bahwa paradigma hubungan merek telah berhasil karena relevansinya untuk memahami loyalitas merek, dikonseptualisasikan sebagai hubungan jangka panjang dengan merek yang diandalkan perusahaan. Teori ini menjelaskan hubungan konsumen dengan merek apa yang ada dalam benak konsumen. Brand loves dipengaruhi oleh beberapa faktor, diantaranya brand relationship (Hegner, 2017), brand loyalty, brand experience (Yao, Wang, \& Liu, 2013), brand image (Sarkar, 2014), brand trust (Albert et al., 2013), brand identification, dan sense of community (Lyu, 2012).

Tujuan penelitian ini adalah: (1) Untuk memperoleh gambaran mengenai tingkat brand identification dan (2) Untuk memperoleh gambaran mengenai tingkat brand loves

\section{KAJIAN PUSTAKA}

Sejak diperkenalkan oleh Shimp dan Madden (1988), kasih merek telah menjadi topik yang sangat menarik bagi manajer merek. Pelanggan dapat melihat merek sebagai individu, sehingga mereka bisa mencintai merek karena mereka mencintai seseorang. Atas dasar (Sternbergs 1986) konseptualisasi cinta interpersonal, Shimp dan Madden dikonsep hubungan konsumen dengan merek bersama tiga dimensi: keinginan, kerinduan dan keputusan atau komitmen, yang sesuai dengan keintiman, gairah dan keputusan atau komponen komitmen cinta antar pribadi. keinginan dan kerinduan mewakili perasaan keintiman dengan dan semangat untuk merek, masing-masing, pada tingkat kognitif, keputusan mengacu pada pengakuan individu dari keinginan dan kerinduan untuk merek dalam jangka pendek; sedangkan komitmen tercermin dalam pembelian merek yang sama berulangulang dari waktu ke waktu. perusahaan saat ini telah mengakui bahwa perasaan cinta terhadap merek merupakan faktor penting dalam membangun hubungan yang baik dengan pelanggan, merek-merek yang dapat membuat pelanggan senang merek mereka lebih sukses dalam memperoleh keuntungan yang berkelanjutan dan mengalahkan pesaing. (Kingdom et al., 2015). Adapun sebagian dari masayarakat belum terlalu familiar dengan forum jual beli di internet secara online, banyak masyarakat merasa takut untuk berbelanja secara online kerena berbelanja secara online dianggap memiliki risiko yang besar dalam pembelian.

Peneliti pemasaran telah menyelidiki konsep brand loves. (Rageh, 2012). Fournier (1998) menjawab pertanyaan apakah konsumen dapat mengalami perasaan cinta terhadap merek, 
serta menetapkan bahwa perasaan seperti itu mungkin ada dan konsumen dapat mengembangkan hubungan yang kuat dengan merek. Cinta merek merupakan perpaduan emosi dan gairah dari seorang individu untuk merek, di samping itu, mereka mendefinisikan cinta untuk merek sebagai tingkat keterikatan emosional yang penuh gairah bahwa seseorang memilikinya untuk perdagangan tertentu.

Konsumen cinta merek meliputi karakteristik sebagai berikut: 1) gairah untuk merek, 2) lampiran merek, 3) evaluasi positif dari merek, 4) emosi positif dalam menanggapi merek, dan 5) deklarasi cinta terhadap brand. Brand loves sebagai tingkat gairah emosional lampiran konsumen puas memiliki untuk nama dagang tertentu Bergkvist, et al., (2009) menyebutkan bahwa cinta merek dan cinta antar pribadi berbeda dalam bahwa brand loves itu searah, sedangkan cinta antar pribadi adalah bidirectional dan bahwa konsumen tidak diharapkan untuk merindukan keintiman hubungan khusus dengan merek, perasaan umumnya terkait dengan cinta antar pribadi yang penuh gairah. Penjelasan cinta umumnya dianggap sebagai kualitatif berbeda dari menyukai, cinta tidak menyukai ekstrim melainkan sebuah konstruksi yang berbeda dari, namun terkait dengan, keinginan.

Satu yang menjelaskan konsumen ikatan emosional miliki dengan merek. Terdiri dari tiga bagian yaitu konsumen, merek dan hubungan di antara. Teori hubungan digunakan untuk menjelaskan hubungan konsumen dengan merek yang diajukan yang pengukuran skala yang akan digunakan. Penelitian cinta kasih merek digunakan, tanpa diskusi kritis, timbangan berasal dari teori hubungan interpersonal. Terhadap latar belakang, kontribusi dari ini adalah untuk menutup kesenjangan ini dengan menyediakan diskusi, pengujian dan membandingkan dua teori hubungan yang berbeda dan skala yang mendasari mereka sebagaimana diterapkan pada cinta merek.

"Brand is a name, term, sign, symbol or design or combination of these, that identifies the maker or seller of a product or services" (Keller, 2013). Penjelasan dari definisi tersebut, dapat dikatakan merek adalah suatu nama, tanda, dan simbol yang membedakan suatu produk atau jasa dengan produk atau jasa lainnya. Apabila merek yang diciptakan perusahaan sudah kuat, maka merek tersebut akan sukses di pasar. Sebuah merek yang sudah sukses di pasar harus mampu memberikan konsumen persepsi kualitas yang unggul.

Merek pada awalnya merupakan tanda tanda khusus yang diberikan dengan satu atau lain cara oleh pemilik produk perusahaan. Kemudian merek diciptakan untuk membantu perusahaan memposisikan diri mereka secara strategis untuk masa yang akan datang dan bersaing secara efektif dengan perusahaan-perusahaan global yang mendominasi pasar. Hasil penelitian menunjukkan cinta atas kepuasan konsumen lebih besar terhadap merek dalam kategori produk hedonis dibandingkan terhadap produk yang bermanfaat, serta kepuasan konsumen lebih besar untuk merek yang menawarkan keuntungan. Brand love is conceptualized here as a mode satisfaction, i.e., a response experienced by some, but not all, satisfied consumers.

Perbedaan penting lainnya muncul juga. Pertama, sementara cinta antar pribadi berisi element yang kuat dari kepedulian altruistik untuk tercinta, ini tidak ditemukan dalam cinta merek. Konsumen yang peduli dengan merek yang bisa dilakukan untuk mereka, bukan apa yang bisa mereka lakukan untuk merek. Kedua, dalam hubungan interpersonal yang sehat, ketika kita mencintai seseorang, mereka kembali cinta kita melalui perilaku mereka membantu ke arah kami dan dengan sesekali mengalami emosi cinta ke arah kami. Sebaliknya, responden mencatat bahwa merek tidak mengalami emosi dan karena itu tidak bisa kembali cinta seseorang dengan cara itu meskipun merek dipandang sebagai kembali cinta konsumen (Batra et al., 2012). Pengertian brand love tersebut tertuju pada sebuah tingkatan kepuasaan konsumen yang menghasilkan sikap konsumen untuk mencintai merek akan tetapi tidak semua konsumen merasakan sebuah kepuasaan untuk mencintai sebuah merek (Fournier, 1998). Brand Love dapat terjadi saat pelanggan dapat melihat brand sebagai suatu individu yang dapat mereka cintai seperti mencintai seseorang. Sebuah merek yang sudah sukses di pasar harus mampu memberikan konsumen persepsi kualitas yang unggul. Merek pada awalnya merupakan tanda tanda khusus yang diberikan dengan satu atau lain cara oleh pemilik produk perusahaan. Merek diciptakan untuk membantu perusahaan memposisikan diri mereka secara strategis untuk masa yang akan datang dan bersaing secara efektif dengan perusahaan-perusahaan global yang mendominasi pasar.

Brand love dalam penelitian ini akan diukur dengan beberapa dimensi yang dikemukakan oleh Sallam, (2014) meliputi:

1. Passion for a brand, perasaan bergairah untuk memiliki suatu produk dengan brand tertentu oleh konsumen. Hal tersebut menunjukkan tingkat cinta konsumen terhadap suatu brand.

2. Brand attachment, perasaan terikat oleh konsumen terhadap suatu brand. Hal ini membuat konsumen merasa harus memiliki setidaknya lebih dari satu produk dari brand tersebut. 
3. Positive evaluation of the brand, setelah pemakaian suatu produk, konsumen biasanya akan memberikan feedback berupa testimoni mengenai produk tersebut. Konsumen yang memliki tingkat brand love yang tinggi akan memberikan testimoni yang baik.

4. Positive emotions in response to the brand, emosi positif yang dirasakan konsumen ketika mengkonsumsi produk juga merupakan indikasi konsumen tersebut memiliki rasa cinta terhadap brand.

5. Declarations of love toward the brand, ketika konsumen sudah mendeklarasikan perasaan cintanya terhadap suatu brand, hal tersebut merupakan bukti dari indikasi baiknya perasaan konsumen terhadap brand itu sendiri.

Konsumen memilih produk dan merek tidak hanya untuk nilai-nilai utilitarian mereka tetapi juga untuk manfaat simbolis mereka. Merek memiliki makna yang dalam, (Roy, 2012) dan melayani untuk membangun konsumen konsep diri atau identitas. Konsumen menggunakan merek untuk membangun diri mereka, menampilkan diri kepada orang lain atau mencapai tujuan identitas mereka (Escalas \& Bettman, 2005). Kuenzel et al., (2010) menyebutkan bahwa konsep identifikasi merek dibangun pada teori identitas sosial, yang telah digunakan secara luas dalam disiplin lain. Identifikasi didasarkan pada teori identitas sosial pada dasarnya merupakan persepsi kesatuan dengan sekelompok orang. identitas sosial dan self - identification (Fatma, 2016). Menggunakan konsep identifikasi dalam konteks merekpelanggan dapat dibenarkan dari segi teori identitas sosial itu sendiri, di mana identifikasi dengan sebuah organisasi juga dapat terjadi tanpa perlu berinteraksi atau memiliki hubungan formal dengan organisasi. Konsumen dengan identifikasi merek kuat lebih rentan untuk terlibat dalam kegiatan pro-merek, seperti mendukung tujuan perusahaan, melindungi reputasinya, mendukung produk dan loyalitas merek (Kingdom et al., 2015).

Brand identification diartikan sebagai seperangkat unik asosiasi merek yang memenuhi jaringan atau mempertahankan strategi pemasaran merek (Ghodeswar, 2008). Definisi lain mengungkapkan bahwa identifikasi merek dibangun berdasarkan teori identitas sosial, yang telah dipekerjakan secara luas dalam disiplin ilmu lainnya. Identifikasi berdasarkan teori identitas sosial pada intinya adalah persepsi kesatuan dengan sekelompok orang (Kuntze, 2010).

Sebagai contoh penerapan pada situs forum jual beli, yaitu dengan dipasangnya logo dan identitas perusahaan pada tampilan situs, sehingga mampu menimbulkan pemikiran positif dari pembeli, serta membuat pembeli bisa membedakan antara situs yang satu dengan situs lainnya (Rahayu \& Wibowo, 2013).

Menurut penelitian yang dijalankan oleh (Sallam, 2014) menjelaskan beberapa dimensi dari brand identification meliputi:

1. Supporting the company goals brand yang baik tentunya akan memberikan efek yang baik pada tercapainya tujuan perusahaan. Sehingga brand tersebut akan diidentifikasi baik pula oleh konsumen. Sebuah brand yang memiliki tujuan pastinya memiliki karakteristik yang dapat ditangkap oleh konsumen.

2. Protecting its reputation dalam pengaplikasiannya, brand dapat menjadi alat untuk menjaga reputasi perusahaan. Brand yang diidentifikasi baik oleh konsumen, akan menaikkan derajat reputasi perusahaan itu sendiri. Seseorang akan menyatakan bahwa sebuah brand adalah barang yang terbaik untuk dapat menjaga reputasi brand.

3. Supporting its products juga berfungsi menjadi pendorong produk perusahaan. Jadi ketika produk tersebut dilihat konsumen, brand yang mewakili produk tersebut akan mudah diidentifikasi oleh konsumen. Pada dasarnya, sebuah brand pastinya memiliki banyak produk dan indikator ini dapat tercermin dari sebanyak apa individu menggunakan sebuah produk dari brand tersebut..

\section{METODE PENELITIAN}

Penelitian ini dilakukan untuk mengalanisis brand identification dalam membentuk brand loves pada pengguna forum jual beli kaskus di Kota Bandung. Variabel bebas (independent variable) atau variabel eksogen yang terdapat pada penelitian ini yaitu brand identification dengan dimensi supporting the company goals, protecting its reputation dan supporting its products. Sedangkan variabel terikat (dependent variable) atau variabel endogen pada penelitian ini yaitu brand loves dengan dimensi Passion for a brand, Brand attachment, Positive evaluation of the brand, Positive emotions in response to the brand dan Declarations of love toward the brand.

Objek/unit analisis pada penelitian ini yaitu pengguna forum jual beli kaskus di Kota Bandung. Penelitian ini dilakukan dalam kurun waktu kurang dari satu tahun, maka metode yang digunakan yaitu cross sectional. Metode penelitian cross sectional merupakan metode di mana data yang dikumpulkan hanya sekali dalam kurun waktu tertentu, mungkin selama beberapa hari, minggu atau bulan, untuk menjawab 
pertanyaan penelitian (Sekaran, 2003), sehingga penelitian ini seringkali disebut penelitian sekali bidik atau one snapshot (Hermawan, 2006).

Data yang digunakan dalam penelitian ini terdiri dari data primer dan data sekunder. Data primer merupakan data yang dikumpulkan secara langsung oleh peneliti untuk menjawab masalah atau tujuan penelitian. Data sekunder merupakan struktur data historis mengenai variabel yang telah dikumpulkan dan dihimpun sebelumnya oleh pihak lain (Hermawan, 2006).

Populasi dalam penelitian ini adalah komunitas forum jual beli Kaskus yang berjumlah 351 orang yang aktif. Teknik pengambilan sampel yang digunakan dalam penelitian ini adalah teknik non-probability sampling dengan jumlah sampel sebanyak 107 responden. Teknik pengumpulan data yang digunakan adalah studi kepustakaan, studi lapangan dengan penyebaran kuesioner, dan studi literatur. Sedangkan teknik analisis data yang dilakukan adalah analisis deskriptif menggunakan distribusi frekuensi.

Alat penelitian yang digunakan dalam penelitian ini adalah angket atau kuesioner yang disusun berdasarkan variabel yang terdapat pada data penelitian, yaitu memberikan keterangan brand identification dan brand loves. Pengolahan data yang terkumpul dari hasil kuesioner dapat dikelompokkan kedalam tiga langkah, yaitu persiapan, tabulasi dan penerapan data pada pendekatan penelitian.

Untuk mengkategorikan hasil perhitungan, digunakan kriteria penafsiran persentase yang diambil dari $0 \%$ sampai $100 \%$. Penafsiran pengolahan data berdasarkan batas-batas disajikan pada Tabel 4 sebagai berikut.

Tabel 4 Kriteria Penafsiran Hasil Perhitungan Responden

\begin{tabular}{ccc}
\hline No & $\begin{array}{c}\text { Kriteria } \\
\text { Penafsiran }\end{array}$ & Keterangan \\
\hline 1 & $0 \%$ & Tidak Seorangan \\
2 & $1 \%-25 \%$ & Sebagian Kecil \\
3 & $26 \%-49 \%$ & Hampir Setengahnya \\
4 & $50 \%$ & Setengahnya \\
5 & $51 \%-75 \%$ & Sebagian Besar \\
6 & $76 \%-99 \%$ & Hampir Seluruhnya \\
7 & $100 \%$ & Seluruhnya \\
\hline
\end{tabular}

Setelah mengkategorikan hasil perhitungan berdasarkan kriteria penafsiran, dibuat garis kontinum yang dibedakan menjadi lima tingkatan diantaranya sangat tinggi, tinggi, sedang, rendah dan sangat rendah. Garis kontinum ini dibuat untuk membandingkan setiap skor total tiap variabel untuk memperoleh gambaran variabel brand loves $(\mathrm{Y})$ dan variabel brand identification (X).

HASIL PENELITIAN DAN PEMBAHASAN Gambaran Brand identification
Variabel brand identification terdiri dari tiga dimensi dengan 8 indikator. Dimensi pertama yaitu supporting the company goals terdiri dari indikator komitmen, perhatian akan brand dan tidak merusak nama merek. Dimensi kedua yaitu protecting its reputation dengan indikator keamananan penjagaan yang diberikan, kewaspadaan terhadap penipuan dan citra yang baik. Dimensi ketiga yaitu supporting its products dengan indikator intensitas pembelian dan penjualan dan informasi produk dan jasa. Hasil pengolahan data mengenai kategori variabel brand identification terlihat pada Gambar 2 berikut ini:

Gambar 2 Garis Kontinum Brand Identification

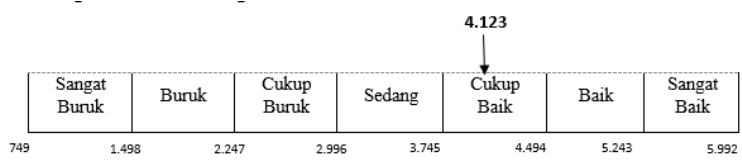

Sumber : Hasil Pengolahan Data, 2018

Berdasarkan hasil pengolahan data yang telah dilakukan, brand identification pada pengunjung Forum jual beli kaskus dapat diukur melalui skor dimensinya. Skor total brand identification sebesar 4.123 sedangkan skor idealnya itu sendiri adalah 5.243. Perbandingan ini menunjukan bahwa pada brand identification pada pengguna forum jual beli kaskus di Kota Bandungtelah berlangsung dengan cukup baik. Secara ideal skor yang diharapkan untuk jawaban pengguna forum jual beli kaskus di Kota Bandung terhadap pertanyaan nomor 1 sampai dengan 8 adalah 5.243. Perolehan skor tersebut secara kontinum berada pada kategori cukup baik dengan interval antara 3.745 dan 4.494.

Dengan adanya hasil ini dapat dikatakan bahwa brand identification pada pengguna forum jual beli Kaskus di Kota Bandung telah berjalan cukup baik namun masih jauh dari yang diharapkan.

Tabel 5 Rekapitulasi Tanggapan Pengguna Mengenai Brand Identification

\begin{tabular}{ccccc}
\hline Dimensi & Skor & $\begin{array}{c}\text { Rata- } \\
\text { Rata } \\
\text { Skor }\end{array}$ & $\begin{array}{c}\text { Skor } \\
\text { Ideal }\end{array}$ & $\%$ \\
\hline $\begin{array}{c}\text { Supporting The } \\
\text { Company Goals } \\
\text { Proctecting It } \\
\text { Reputations }\end{array}$ & 1168 & 584,00 & 749 & 77,97 \\
Supporting Its Product & 1764 & 588,00 & 749 & 78,50 \\
\hline Total & $\mathbf{4 1 2 3}$ & 1767,50 & 2247 & 78,66 \\
\hline
\end{tabular}

Sumber : Hasil Pengolahan Data, 2018

Tabel 5 menjelaskan mengenai rekapitulasi skor dari dimensi-dimensi yang ada pada brand 
identification. Besarnya skor yang dimiliki setiap dimensi dari brand identification dapat menjelaskan bahwa adanya pengaruh yang cukup besar dalam brand loves pada komunitas Kaskus. Brand identification berdasarkan item pernyataan (indikator) menunjukkan bahwa nilai tertinggi berada pada dimensi Supporting Its Product Brands sebesar 79\%. Hal ini menunjukkan bahwa terlaksananya brand identification di forum jual beli Kaskus di Kota Bandung. Sedangkan untuk dimensi dengan nilai terendah yaitu dimensi dengan Supporting The Company Goals perolehan $77 \%$. Hal ini menunjukkan bahwa dimensi ini tidak terlalu mempengaruhi konsumen Forum jual beli kaskus . Hal ini sesuai dengan penelitian terdahulu yang mengemukakan bahwa Supporting the company goals yang baik tentunya akan memberikan efek yang baik pada tercapainya tujuan perusahaan. Sehingga brand tersebut akan diidentifikasi baik pula oleh konsumen. Sebuah brand yang memiliki tujuan pastinya memiliki karakteristik yang dapat ditangkap oleh konsumen. (Sallam, 2014). Supporting the company goals brand yang baik tentunya akan memberikan efek yang baik pada tercapainya tujuan perusahaan. Sehingga brand tersebut akan diidentifikasi baik pula oleh konsumen. Sebuah brand yang memiliki tujuan pastinya memiliki karakteristik yang dapat ditangkap oleh konsumen (Sallam, 2014).

FJB Kaksus telah melakukan pendukungan dengan meibatkan anggotanya. Berdasarkan data yang diperoleh pada dimensi supporting the company goal brand, perolehan skor tertinggi terdapat pada indikator dukungan tidak merusak nama Forum jual beli kaskus, sedangkan skor terendah terdapat pada indicator komitmen untuk membayar lebih dalam menggunakan Forum jual beli kaskus, hal ini menunjukkan bahwa komitmen untuk membayar dalam menggunakan Kaskus kurang memengaruhi brand identification. Penelitian terdahulu menjelaskan konsumen dengan mendukung brand yang kuat akan lebih berpengaruh untuk terlibat dalam kegiatan brand, seperti mendukung tujuan perusahaan, melindungi reputasinya, mendukung produk dan menjaganya dengan baik (Kingdom et al., 2015).

Selain memberikan dukungan terhadap forum jual beli dan perasaan pengunjung Forum jual beli kaskus memberikan keamanan dan kenyamanan dalam menggunakannya. Perolehan skor tertinggi terdapat pa indikator dari dimensi protecting its reputation yang mendapat nilai tertinggi yaitu pada keamanan dalam transaksi pada Forum jual beli kaskus . Sedangkan untuk perolehan skor terendah yaitu pada indikator Kemungkinan terhadap penipuan pada Forum jual beli kaskus sebesar 569 .
Hasil penelitian memberikan informasi bahwa forum harus benar-benar memperhatikan aspek-aspek dalam membangun protecting its reputation pengguna agar memperoleh penilaian yang baik. Temuan ini sesuai dengan penelitian Sallam (2014) dalam pengaplikasiannya, brand dapat menjadi alat untuk menjaga reputasi perusahaan. Brand yang diidentifikasi baik oleh konsumen, akan menaikkan derajat reputasi perusahaan itu sendiri.

\section{Gambaran Brand Loves}

Variabel brand loves terdiri dari lima dimensi dengan 16 indikator. Dimensi pertama yaitu Passion for a brand dengan indikator fanatisme terhadap merek dan gaya hidup dalam membeli. Dimensi kedua yaitu Brand attachment terdiri dari affection pada brand, ingatan pada brand dan ketertarikan membeli lebih dari satu pada Forum Jual Beli Kaskus. Dimensi ketiga yaitu Positive evaluation of the brand terdiri dari indikator kualitas web dan aplikasi, keunggulan dari produk yang dibeli atau dijual, kualitas barang atau jasa, kemudahan pelayanan dan keceoatan pelayanan. Dimensi berikutnya yaitu Positive emotions in response to the brand dengan indikator rasa senang, rasa suka pada merek dan rasa bangga pada merek. Dimensi terakhir adalah Declarations of love toward the brand indikatornya terdiri dari duration of the relationship, kekeluargaan dan menerima perubahan. Hasil pengolahan data mengenai kategori variabel brand loves terlihat pada Gambar 3 berikut ini :

\section{Gambar 3 Garis Kontinum Brand Loves}

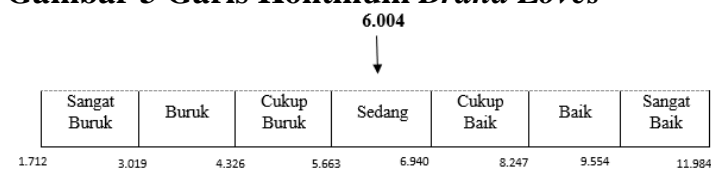

Sumber : Hasil Pengolahan Data, 2018

Berdasarkan hasil penelitian dari kuesioner yang disebar kepada 107 responden dapat diketahui bahwa brand loves Foum Jual Beli Kaskus di Kota Bandung mendapatkan skor total 6.004. Berdasarkan hasil pengolahan data yang telah dilakukan, brand loves pada pengguna forum jual beli Kaskus dapat diukur melalui skor dimensinya. Skor total brand loves sebesar 6.004 atau sebesar $50,1 \%$ dari skor idealnya yaitu 11.984. Perbandingan ini menunjukan bahwa gambaran brand loves pada pengguna forum jual beli Kaskus di Kota Bandung berada pada kategori sedang yaitu pada interval antara 5.663 dan 6.940. Secara ideal skor yang diharapkan untuk jawaban pengunjung forum jual beli 
Kaskus di Kota Bandung terhadap pertanyaan nomor 1 sampai dengan 16 adalah 11.984 .

Dengan hasil perolehan ini dapat dikatakan bahwa brand loves pada pengguna forum jual beli Kaskus di Kota Bandung belum menunjukkan kinerja yang diharapkan karena tngkat brand loves dari penggunanya masih berada di angka rata-rata atau kategori sedang.

Tabel 6 Rekapitulasi Tanggapan Konsumen Mengenai Brand Loves

\begin{tabular}{|c|c|c|c|c|}
\hline Dimensi & Skor & $\begin{array}{l}\text { Rata- } \\
\text { Rata } \\
\text { Skor }\end{array}$ & $\begin{array}{l}\text { Skor } \\
\text { Ideal }\end{array}$ & $\%$ \\
\hline $\begin{array}{l}\text { Passion } \quad O f \\
\text { Brands }\end{array}$ & 1166 & 583 & 749 & 77,84 \\
\hline $\begin{array}{l}\text { Brand Attacment } \\
\text { Positive }\end{array}$ & 1823 & 607,67 & 749 & 81,13 \\
\hline $\begin{array}{l}\text { Evalutions } \quad \text { Of } \\
\text { Brands }\end{array}$ & 2396 & 479,20 & 749 & 63,98 \\
\hline Positive Emotions & 1787 & 595,67 & 749 & 79,53 \\
\hline $\begin{array}{l}\text { Declarations } \quad \text { of } \\
\text { Loves }\end{array}$ & 1821 & 607 & 759 & 79,97 \\
\hline Total & 6004 & 1681,87 & 2257 & 74,52 \\
\hline
\end{tabular}

Sumber : Hasil Pengolahan Data, 2018

Berdasarkan Tabel 6 dapat diketahui bahwa jika dilihat berdasarkan dimensi, brand attachment mendapat persentase ketercapaian tertinggi dengan skor rata-rata 607,67 atau $81,13 \%$ dari skor ideal 749 dan dimensi positive evaluations of brands mendapat persentase ketercapaian terendah dengan tingkat skor 479,20 atau $63,98 \%$ dari skor ideal 749 .

Hasil penelitian menunjukkan bahwa brand attahment merupakan dimensi penting yang menjadi sebuah pondasi untuk membentuk brand loves (Sallam, 2014). Brand Loves yang tinggi dipengaruhi oleh peningkatan dan penguatan persepsi pelanggan terhadap kesadaran merek karena elemen penting dalam menciptakan nilai. Kesadaran merek harus menunjukkan bahwa merek yang dituju merupakan merek yang menguntungkan, sesuai dengan harapan yang di pikirkan para konsumen. Brand loves memiliki dampak bagi pemilihan merek konsumen, komitmen merek, perluasan merek, dan kinerja bisnis sebuah perusahaan (Çifci et al., 2016). Integritas diperlukan dalam menciptakannya kekuatan cinta persepsi trustor bahwa trustee akan bertahan pada seperangkat prinsip yang telah diberikan kepada trustor. Apa yang telah diucapkan oleh trustee kepada trustor harus sama dengan tindakan yang akan trustee lakukan dan konsumen memiliki keingintahuan apakah trustee dapat melakukan hal yang sama seperti yang telah dijaminkan (Susanti dan Cholichul, 2013:3).

Konsumen mencintai suatu merek karena merek tersebut mampu meningkatkan minat yang bisa menginspirasi konsumen tersebut. Konsumen mau menggunakan suatu merek dengan baik serta mereka ingin mendapatkan informasi yang terbaru dari merek yang dicintai. Merek yang sudah dicintai konsumen, mudah untuk memasarkan produk barunya. Merek yang dicintai juga memiliki keterikatan dengan konsumennya serta antara merek dan konsumen akan terbentuk suatu pondasi yang solid, sehingga konsumen akan menyampaikan opini-opini baiknya kepada calon konsumen lain. Transaksi online melibatkan berbagai informasi dan tindakan pembelian, dan niat pembelian akan tergantung kepada banyak faktor. Perusahaan dan pemasar melakukan beberapa strategi yang bertujuan untuk memudahkan para konsumen dalam penerimaan teknologi dan menumbuhkan niat untuk pembelian secara online tentu akan menghasilkan cinta merek yang sangat melekat pada hati pengguna (Widjajanta \& Haekal, 2016). Hal tersebut dimaksudkan untuk mempermudah konsumen dalam membeli produk

Berdasarkan data yang diperoleh melalui hasil penelitian, indikator yang memiliki nilai paling tinggi pada dimensi declaration of love yaitu Kemampuan Forum jual beli Kaskus untuk melakukan perubahan dengan perolehan skor 628 . Hal ini menunjukkan bahwa berdasarkan penilaian pengguna, kemampuan forum jual beli kaskus dalam melakukan perubahan sudah berjalan dengan baik. Hasil penemuan tersebut seuai dengan temuan penelitian Sallam (2014) bahwa ketika konsumen sudah mendeklarasikan perasaan cintanya terhadap suatu brand, hal tersebut merupakan bukti dari indikasi baiknya perasaan konsumen terhadap brand itu sendiri terutama pada forum jual beli Kaskus. Orang yang mengetahui bahwa dirinya cinta akan brand adalah kompetensi individu dari hati dengan orang sekitar sehingga untuk kesuksesan masa depan perusahaan dan pengguna tidak lengkap jika hanya fokus pada pengembangan teknologi dan pasar, tetapi juga harus dapat fokus pada pengembangan sumber daya manusia (Astuty et al., 2018).

Sementara indikator dengan tanggapan terendah berada pada dimensi Passion of Brands yaitu Keinginan atas pilihan forum jual beli di Kaskus dengan perolehan skor 580. Hasil ini menunjukkan bahwa sikap pengguna dalam memilih dan menggunakan forum jual beli di Kaskus masih menjadi pertimbangan paling rendah. Hal ini harus menjadi perhatian bagi perusahaan mengingat pentingnya pemilihan pegguna untuk menggunakan forum jual beli kaskus secara berkesinambungan di kemudian hari. Temuan ini sesuai dengan Sallam, (2014) yang mengungkapkan bahwa dalam pengaplikasiannya, perasaan bergairah untuk memiliki suatu produk dengan brand tertentu oleh konsumen, hal tersebut menunjukkan tingkat 
cinta konsumen terhadap suatu brand terutama pada forum jual beli Kaskus.

\section{Implikasi Penelitian}

Teori serta konsep brand loves yang digunakan dalam penelitian ini mengadopsi dan memodifikasi teori serta konsep menurut Madden, (2007) yang mengemukakan bahwa brand loves hubungan konsumen dengan merek bersama tiga situasi yaitu keinginan, kerinduan dan keputusan atau komitmen, yang sesuai dengan keintiman, gairah dan keputusan atau komponen komitmen cinta antar pribadi (Sallam, 2014). Dalam penelitian ini dilakukan identifikasi terhadap dimensi-dimensi yang membentuk brand loves sepuluh secara keseluruhan dan didapatkan adanya lima dimensi yang menjadi pembentuk utama brand loves yang diperoleh dari berbagai literatur dan penelitian terdahulu. Untuk keperluan penelitian, ke sepuluh dimensi tersebut dikelompokkan berdasarkan justifikasi kategori yang sama dan terbentuklah lima dimensi yang digunakan dalam penelitian ini yang terdiri dari 1) Passion for a brand, 2) Brand attacment, 3) Positive evaluation of the brand, 4) Positive emotions in response to the brand, dan 5) Declarations of loves. Selanjutnya lima dimensi awal tersebut dijadikan sebagai indikator dari masing-masing dimensi yang telah dibentuk. Sedangkan Teori serta konsep brand identification yang digunakan dalam penelitian ini mengadopsi dan memodifikasi teori serta konsep menurut Sallam (2014) yang mengemukakan bahwa brand identification lebih mengidentifikasi suatu merek untuk terjadinya interaksi langsung antara perusahaan dan konsumen melainkan hanya melalui produk dan persepsi yang ditanamkan oleh perusahaan dalam benak konsumen. Meskipun demikian, hubungan langsung terkuat antara perusahaan dan pengguna merek dihasilkan dari pilihan produk. Dalam penelitian ini dilakukan identifikasi terhadap dimensi-dimensi yang membentuk brand identification secara keseluruhan dan didapatkan adanya lima dimensi yang menjadi pembentuk utama brand identification yang diperoleh dari berbagai literatur dan penelitian terdahulu. Penelitin terdahulu menjelaskan mengembangkan skala bagaimana dampak dari adanya identifikasi merek dengan baik dan jelas. Untuk keperluan penelitian, ke lima dimensi tersebut dikelompokkan berdasarkan justifikasi kategori yang sama dan terbentuklah tiga dimensi yang digunakan dalam penelitian ini yang terdiri dari 1) Supporting the company goals brand, 2) Protecting Its Reputation, dan 3) Supporting Its Products. Selanjutnya lima dimensi awal tersebut dijadikan sebagai indikator dari masing-masing dimensi yang telah dibentuk. Penelitian yang dilakukan oleh Sallam (2014) menunjukkan bahwa terdapat dampak brand identification terhadap brand loves. Pada penelitian terdahulu juga didapatkan hasil bahwa di beberapa industri menunjukan bahwa brand loves dipengaruhi oleh brand identification. Sehingga perusahaan perlu memperhatikan bagaimana caranya memberikan pengaruh antara merek yang mengesankan kepada konsumen.

\section{KESIMPULAN DAN REKOMENDASI}

Berdasarkan hasil penelitian di pembahasan dikemukakan kesimpulan sebagai berikut:

Gambaran mengenai brand identification dapat dilihat dari dimensi-dimensinya yang terdiri supporting the company goals, protecting its reputation dan supporting its products berada pada kategori cukup baik. Hal ini menunjukan bahwa identifikasi merek yang dirasakan pengguna forum jual beli Kaskus di Kota Bandung dapat dikatakan cukup baik secara keseluruhan. Dimensi yang memperoleh tanggapan yang paling tinggi yaitu dimensi supporting its products, sedangkan dimensi dengan perolehan tanggapan paling rendah adalah dimensi supporting the company goals. Gambaran brand loves pada pengguna forum jual beli Kaskus di Kota Bandung dapat dilihat dari dimensi-dimensinya yang terdiri dari dimensi Passion for a brand, Brand attachment, Positive evaluation of the brand, Positive emotions in response to the brand dan Declarations of love toward the brand berada pada kategori sedang. Hal ini menunjukan bahwa kondisi brand loves yang dimiliki Forum Jual Beli Kaskus belum menunjukkan kinerja yang baik. Dimensi yang memperoleh tanggapan paling tinggi adalah dimensi brand attachment dan dimensi dengan perolehan tanggapan paling rendah adalah positive evaluation for a brands.

Forum jual beli juga berusaha memperbaiki pengalaman pengguna dengan, menggunakan pengetahuan tentang pelanggan, memberikan pelayanan prima secara konsisten sehingga akan tercipta kecintaan yang melekat pada pengguna. Kepuasan pengguna ini bisa tercipta kalau perusahaan mampu menciptakan nilai yang superior kepada pelanggan yang pada akhirnya akan menciptakan citra positif bagi perusahaan. Perusahaan menciptakan nilai yang superior dengan cara membangun suatu proposisi nilai yang superior serta membangun sistem penyampaian nilai yang superior pula (Wibowo, 2011).

Adanya penelitian ini diharapkan dapat membantu peneliti berikutnya dalam melakukan penelitian mengenai brand identification dan brand loves dengan menggunakan indikator yang berbeda dari sumber teori yang lebih beragam, 
dan terhadap objek yang berbeda, karena masih banyaknya keterbatasan dalam penelitian ini, khususnya yang berkaitan dengan metode penelitian dan teknik pengumpulan data. Penelitian ini diharapkan dapat membantu perusahaan untuk memperhatikan langkahlangkah melakukan analisis kondisi brand identification dan brand loves agar dapat mengoptimalkan kinerjanya.

Indikator dari brand identification yang paling rendah adalah tingkat supporting the company goals, perusahaan harus mampu mengembangkan dan melakukan perbaikan dalam berbagai aspek agar mendapatkan respon yang baik dari para pengguna agar mampu mendukung tujuan perusahaan dengan baik. Beberapa strategi yang dapat dilakukan forum jual beli Kaskus diantaranya harus bisa menawarkan fitur-fitur yang unik dan bermanfaat bagi pengguna sehingga mempermudah segala macam bentuk transaksi yang dilakukan dalam forum jual beli kaskus di Kota Bandung. Dengan demikian maka identifikasi merek dari pengguna terhadap perusahaan mampu menunjukkan hal-hal yang dapat mendukung tujuan perusahaan.

Indikator dari brand loves yang paling rendah adalah aspek positive evaluation of brands. Untuk meningkatkan positive evaluation of brands, Forum jual beli Kaskus harus mengembangkan strategi pemasaran melalui peningkatan citra merek, dimana forum jual beli Kaskus harus mampu meningkatkan pelayanan lalu mengurangi hal-hal yang mampu merugikan para penggunanya sehingga para pengguna ingin menggunakan forum jual beli kaskus secara berkesinambungan dan memiliki persepsi merek yang positif. dengan begitu mampu meningkatkan penilaian terhadap evaluasi merek yang positif.

\section{DAFTAR PUSTAKA}

Abosag, I., Roper, S., \& Hind, D. (2012). Examining the relationship between brand emotion and brand extension among supporters of professional football clubs, 46(9), 1233-1251. https://doi.org/10.1108/0309056121124781 0

Albert, N., \& (2013), D. M. (2013). Noel Albert, Dwight Merunka (2013), (1988), 7-19.

Albert, N., Management, E., \& Merunka, D. (2013). The role of brand love in consumerbrand relationships, (1988). https://doi.org/10.1108/0736376131132892 8

Astuty, E., Widyatama, U., Rahayu, A., Indonesia, U. P., Indonesia, U. P., Wibowo, L. A., \& Indonesia, U. P. (2018). Breakthrough in Indonesian Creative Industry Through Soft Innovation, 22(2), 1-
10.

Baena, V. (2016). Online and mobile marketing strategies as drivers of brand love in sports teams Findings from Real Madrid. International Journal of Sports Marketing and Sponsorship, 17(3), 202-218. https://doi.org/10.1108/IJSMS-08-2016-015

Batra, R., Ahuvia, A., Bagozzi, R. P., \& Love, B. (2012). Brand Love, 76(March), 1-16.

Çifci, S., Ekinci, Y., Whyatt, G., Japutra, A., Molinillo, S., \& Siala, H. (2016). A cross validation of Consumer-Based Brand Equity models: Driving customer equity in retail brands. Journal of Business Research, 69(9), 3740-3747. https://doi.org/10.1016/j.jbusres.2015.12.06 6

Cortsen, K., \& Cortsen, K. (2013). “ renstam - a hybrid Annika So personal sports brand. https://doi.org/10.1108/2042678131131689 8

Escalas, J. E., \& Bettman, J. R. (2005). SelfConstrual, Reference Groups, and Brand Meaning, 37203.

Evans, D. M., \& Smith, A. C. T. (2004). Internet sports marketing and competitive advantage for professional sports clubs: Bridging the gap between theory and practice. Internet Sports Marketing and Competitive Advantage for Professional Sports Clubs: Bridging the Gap between Theory and Practice, 6(2), 86-98.

Fatma, M. (2016). How does corporate association influence consumer brand loyalty? Mediating role of brand identification. Retrieved from http://dx.doi.org/10.1108/JPBM-07-20150932

Fournier, S. (1998). Consumers and Their Brands : Developing Relationship Theory in Consumer Research, 24(March), 343-373.

Ghodeswar, B. M. (2008). Building brand identity in competitive markets: a conceptual model, 1 , 4-12. https://doi.org/10.1108/1061042081085646 8

Hegner, S. M. (2017). Using the Theory of Planned Behaviour to understand brand love.

Hermawan, A. (2006). Penelitian Bisnis: Paradigma Kuantitatif. Jakarta: Grasindo.

Keller, K. L. (2013). Strategic Brand Management (FOURTH EDI). Perason.

Kingdom, U., Sallam, M. A., Arabia, S., Wahid, N. A., \& Network, C. (2015). The Effect Of Satisfication and Brand Identification On Brand Love And Brand Equity, III(2), 113.

Kuntze, R. (2010). No Title. 
Lyu, J. W. (2012). The Role of Sense of Community in Online Brand Social Networking Sites.

Norris, J. I., Wann, D. L., \& Zapalac, R. K. (2015). Sport fan maximizing: following the best team or being the best fan? Journal of Consumer Marketing, 32(3), 157-166. https://doi.org/10.1108/JCM-02-2014-0856

Popp, B., Germelmann, C. C., \& Jung, B. (2016). We love to hate them! Social media-based anti-brand communities in professional football, 17(4), 349-367. https://doi.org/10.1108/IJSMS-11-2016-018

Rageh, A. (2012). Journal of Fashion Marketing and Management: An International Article information:

Rahayu, A., \& Wibowo, L. A. (2013). Analisis Nilai Pengalaman Berbelanja Online Melalui Experiential Marketing. Jurnal Ilmu Manajemen Dan Bisnis, 04(01), 1-15.

Roy, S. (2012). To Use the Obvious Choice: Investigating the Relative Effectiveness of an Overexposed Celebrity, 41-69.

Sæther; S. A. \& S. H. A. (2014). The Impact of Social Networks in the Development of a Personal Sports Brand.

Sallam, M. A. (2014). Sallam, M. A. (2014). The Effects of Brand Image and Brand Identification on Brand Love and Purchase Decision Making: The Role of WOM, $7(10)$, 187-193. http://doi.org/10.5539/ibr.v7n10p187The Effects of Brand Image and Brand Identification on Brand Love a, 7(10), 187-
193. https://doi.org/10.5539/ibr.v7n10p187

Sarkar, A. (2014). Brand love in emerging market: a qualitative investigation. https://doi.org/10.1108/QMR-03-2013-0015

Sekaran, U. (2003). Research Methods for Business: A Skill-Building Approach (4th ed.). England: John Wiley \& Sons, Inc. https://doi.org/10.13140/RG.2.1.1419.3126

Wibowo, L. A. (2011). Pembentukan Citra Taman Rekreasi DKI Jakarta Sebagai Green City Mellui Kualitas Penyampaian Jasa dan Value Creation (Studi Pada Para Pengunjung Taman-Taman Rekreasi Di DKI Jakarta). Tourism and Hospitality Essentials Journal, I(1), 1-14.

Widjajanta, B., \& Haekal, A. (2016). Pengaruh Kepercayaan dan Persepsi Risiko Terhadap Minat Membeli Secara Online Pada Pengunjung Website Classifieds di Indonesia. Journal of Business Management \& Entrepreneur Education, 1(1), 181-193.

Williams, A. S., Pedersen, P. M., \& Walsh, P. (2012). Brand associations in the fitness segment of the sports industry in the United States : extending spectator sports branding conceptualisations and dimensions to participatory sports.

Yao, J., Wang, X., \& Liu, Z. (2013). Brand Management Innovation: A Construction of Brand Experience Identification System. Journal of Applied Sciences, 13(21), 44774482.

https://doi.org/10.3923/jas.2013.4477.4482 